\title{
MEDICALL JoURnal
}

\section{Clinical and radiological postoperative evaluation of posterior sagittal anorectoplasty in patients with upper and intermediate anorectal malformations}

Department of Imaging Diagnosis, Discipline of Pediatric Surgery of the Department of Surgery Universidade Federal de São Paulo - São Paulo, Brazil

The PSARP is today the most-used surgical technique for correction of high and intermediary anorectal malformations. There is much controversy in the literature about the post-operative evaluation of these cases. We studied 27 cases of anorectal malformations from clinical and radiological aspects, in order to analyse: 1 .Fecal continence 2.Relationship between post-operative fecal continence and the associated sacral anomalies 3 . Relationship between the radiological evaluation by defecogram and fecal continence

From the analysis of the cases, we concluded: 1 . Fecal continence was achieved in $48.14 \%$ of the cases; partial continence in $25.92 \%$; and fecal incontinence in $25.92 \%$ of the cases. 2. The presence of fecal incontinence was directly related to the associated sacral anomalies.

UNITERMS: Anorectal malformations. Posterior sagittal anorectoplasty.

\section{INTRODUCTION}

S ince studies done by Peña and DeVries', posterior sagittal anorectoplasty (PSARP) has become the main treatment for upper and intermediate anorectal malformations (ARM) around the world.

However, careful long term evaluation must be done to allow complete approval of this method.

Therefore, we analyzed clinical and radiological assays of 27 children with upper and intermediate ARMs who underwent PSARP.

\section{Address for correspondence:}

José Luiz Martins

Rua dos Otonis, 131. V. Clementino

São Paulo/SP - Brasil - CEP 04025-000

\section{PATIENTS}

We studied 27 white children with 21 upper and 6 intermediate ARMs, of which 17 were male and 10 were female, who underwent colostomies, PSARPs, and anal dilations with Hegar's candle, after which the colostomies were closed; ages varied from 4 to 11 years. We selected patients who were over 4 years old because at this age fecal continence is well-developed in normal children. All children were evaluated 3 months or more after the colostomies were closed.

All children were evaluated clinically and radiologically by defecograms using the Haberkorn technique ${ }^{2}$ for the following parameters:

1. Fecal continence

2. Relation between fecal continence and the presence of sacral malformations 
3. Relationship between fecal continence and dynamic radiology evaluation by defecogram, analyzing the following features:

a) Presence of rectal reservoir

b) Presence of fecaloma

c) Impression on posterior rectum caused by the contractions of the puborectalis of the levator ani, which is part of the superior sphincter muscular complex

d) Absence of inferior sphincter muscular complex tightening, which is formed by the sphincter ani externs and is demonstrated by constant evacuation

Children who: defecated once or twice a day; with no soiling; whose feces and anus presented no alterations; with good upper and lower rectal contraction during examination were considered continent.

Children who: defecated three to five times a day; with normal feces and frequent soiling; who presented rectal prolapse; with moderate upper or lower contraction during rectal examination were considered partially continent.

Children who: defecated more than five times a day; with liquid feces; constant and total fecal loss; anus with a large opening, or rectal prolapse, and loss of feces; with light or nil upper or lower contraction during examination were considered incontinent ${ }^{3}$.

We used chi-square test for statistical analysis of table 2 to compare continent, partially continent, and incontinent patients according to the characteristics above. We used Fisher's exact test ${ }^{4}$ to associate continent, partially continent, and incontinent patients' tightening of external sphincter; the level of significance used was $5 \%(\mathrm{p} \leq 0.05)$.

\section{RESULTS}

\section{Fecal Continence}

Thirteen of the 27 cases presented fecal continence, 7 cases presented partial continence, and 7 presented incontinence.

Eight of the thirteen continent patients had upper ARMs and 5 had intermediate ARMs; six of the seven partially continent patients had upper ARMs and 1 had an intermediate ARM; all 7 incontinent patients had upper ARMs.

Distribution according to gender was the following:

Continent - 7 male and 6 female.

Partially continent - 5 male and 2 female.

Incontinent - 5 male and 2 female.

\section{Relation Between Fecal Continence and Associated Sacral Malformations}

One of the thirteen continent children presented an associated sacral malformation; 3 of the seven partially continent children presented associated sacral anomalies; six of the seven incontinent children presented associated sacral anomalies.

Vertebral malformations found in these patients can be seen in Table 1.

\section{Table 1}

Associated Vertebral Malformations

\begin{tabular}{|c|c|}
\hline Case & Malformation \\
\hline 4 & Fusion of vertebrae 4 and 5 . Absent Coccyx \\
\hline 6 & Absence of 5 sacral vertebrae and coccyx \\
\hline 7 & $\begin{array}{l}\text { Fusion of sacral vertebrae } 2,3 \text {, and } 4 \text {. } \\
\text { Absence of } 5 \text { sacral vertebrae and coccyx }\end{array}$ \\
\hline 10 & $\begin{array}{l}\text { Fusion of all sacral vertebrae. Absence of } \\
\text { coccyx. Lombosacral hemivertebra. Scoliosis }\end{array}$ \\
\hline 11 & Absence of sacral vertebrae 5 and coccyx \\
\hline 13 & $\begin{array}{l}\text { Fusion of sacral vertebrae } 2,3 \text {, and } 4 \text {. } \\
\text { Absence of sacral vertebrae } 5 \text { and coccyx }\end{array}$ \\
\hline 15 & Absence of sacral vertebrae 5 and coccyx \\
\hline 19 & $\begin{array}{l}\text { Fusion of sacral vertebrae } 1,2,3 \text {. Absence } \\
\text { of vertebrae } 4,5 \text {, and coccyx. Hemiagenesia } \\
\text { of left remaining sacral vertebrae. }\end{array}$ \\
\hline 24 & $\begin{array}{l}\text { Scimitar vertebra } 5 \text {. Increase of } \\
\text { interpedicular space between sacral } \\
\text { vertebrae } 1 \text { and } 2 \text {. }\end{array}$ \\
\hline 25 & Absence of sacral vertebra 5 and coccyx \\
\hline
\end{tabular}

\section{Relation Between Fecal Continence and Defecogram}

Results are shown in Table 2.

TABLE 2

Continence vs. Defecogram

\begin{tabular}{lccccc}
\hline N & RR & FEC & AA & IMP & TIC \\
\hline Continence 13 & 13 & 0 & 13 & 13 & 13 \\
Partial Cont. 7 & 7 & 1 & 7 & 7 & 7 \\
Incontinence 7 & 5 & 1 & 6 & 6 & 2 \\
\hline
\end{tabular}

$\mathrm{N}=$ number of evaluated patients

$\mathrm{RR}=$ rectal reservoir

$\mathrm{FEC}=$ fecaloma

$\mathrm{AA}=$ anorectal angle alteration during evacuation

IMP = Impression of the superior sphincter complex on posterior rectum

TIC = tightening of inferior sphincter complex

There was a significant association between incontinence and absence of tightening of external sphincter in the defecogram (Fig. 1 and 2). 


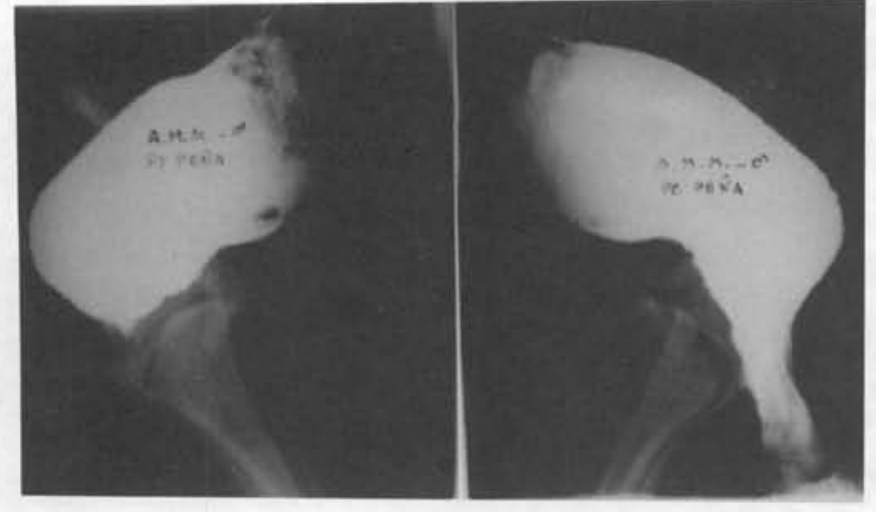

Figure 1 - Tightening of external sphincter in continent patient

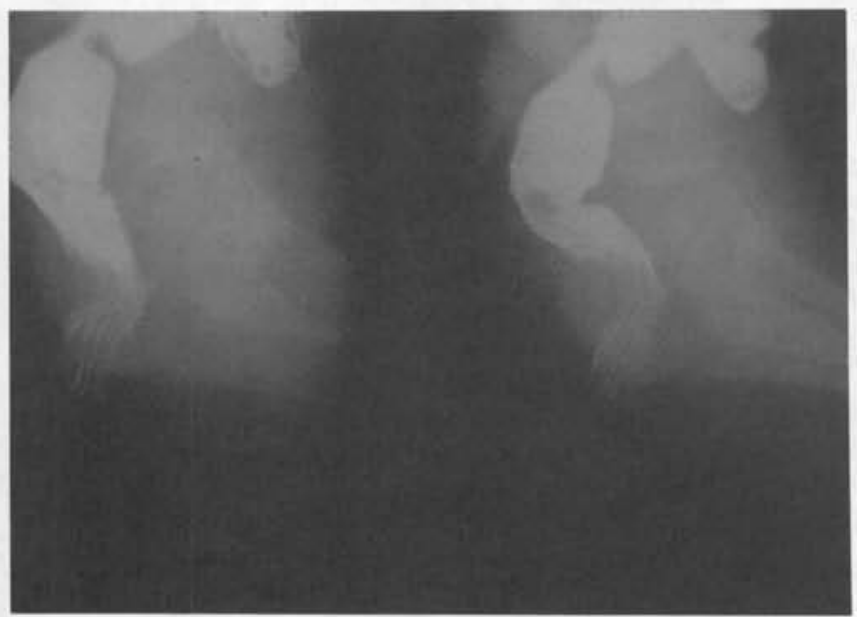

Figure 2-Absence of external sphincter tightening in incontinent patient.

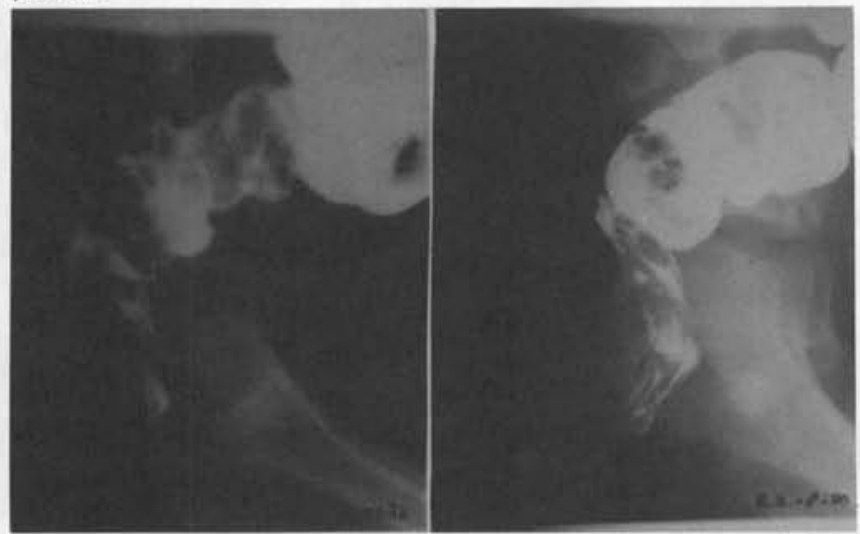

Figure 3 - Absence of external sphincter tightening associated with fibrosis in incontinent patient

\section{DISCUSSION}

Postoperative evaluation of fecal continence after correction of ARMs has been controversial, and a consensus has not been reached in spite of numerous reports $(5,6,7$ and 8).
Our clinical evaluation is based on a blend of what has been proposed recently.

Our results agree with those by other authors, with the exception of Lanjemeijer \& Mollenaar - 1991 (9), who stated that this surgical technique never allows normal fecal continence.

The presence of sacral malformations have an effect on fecal continence especially in upper ARM. Clinical manifestations are greater when entire sacral sections are not present, but even hemisacral malformations may be occasionally responsible for nerve involvement; therefore, it is important to observe the following data:

1. Innervation of levator ani and bladder are usually normal in malformations of vertebrae 4 and 5 .

2. Malformations of sacral vertebrae 3,4 , and 5 lead to variable innervation of bladder and levator ani, but most patients become incontinent.

3. Malformations of sacral vertebrae 1 and 2 are associated with incontinence since the levator ani not only presents problems with its innervation but also is underdeveloped.

4. Hemisacral malformations are unpredictable; involvement of vertebrae 4 and 5 in these cases usually leads to bladder and levator ani malfunctions.

In our study, $42.85 \%$ of the partially continent and $85.71 \%$ of the incontinent patients presented sacral malformations. These results agree with studies of Peña ${ }^{10}$ and Martins", which state that sacral malformations are usually associated with neurological problems and muscle weakening.

Evaluation of patients using defecograms in our study was consistent with fecal continence, although many authors consider puborectal impression on the posterior rectum to be more important, eg: Kelly ${ }^{12,13}$, Cywes et $\mathrm{al}^{14}$.

These authors report that the puborectal impression on the posterior rectum gives a better idea of the function of the sphincter and its relation to fecal continence. Our study does not agree since all patients, including the incontinent ones, presented a puborectal impression on the posterior rectum, with only one exception.

Our results show that the best parameter is the tightening of the external anal sphincter, which was present in all continent patients and not present in $71.42 \%$ of the incontinent patients.

Other features, such as the rectal reservoir, the presence of fecaloma, and the alteration of anorectal angle did not show any significant results in the evaluation of postoperative continence. 


\section{CONCLUSIONS}

1. PSARP was efficient in maintaining fecal continence in $48.14 \%$ of the cases and partial fecal continence in $25.92 \%$ of the cases.
2. Fecal incontinence was associated directly with sacral malformations.

3. Absence of external anal sphincter tightening in patients with fecal incontinence, as demonstrated by defecograms, was significantly higher.

\section{Resumo}

A ARPSP é atualmente uma das técnicas mais utilizadas na correção cirúrgica das anomalias anorretais altas e intermediárias, existindo muita controvérsia na literatura quanto aos critérios de avaliação desses pacientes no pós-operatório. Foram estudados 27 pacientes do ponto de vista clínico e radiológico pelo defecograma, submetidos à ARPSP, visando avaliar os seguintes parâmetros: 1. Continência fecal; 2. Relação entre a continência fecal e as anomalias sacrais associadas; 3 . Relação entre a avaliação radiológica dinâmica pelo defecograma e a continência fecal. Da análise da casuística foram obtidas as seguintes conclusões: 1.A continência fecal foi obtida em $48,14 \%$ dos casos; parcialmente em $25,92 \%$ dos casos; e a incontinência fecal foi observada em $25,92 \%$ dos casos.2. A ocorrência de incontinência fecal esteve diretamente relacionada com a associação de anomalias sacrais. 3.Nos pacientes com incontinência fecal, a ausência de oclusão do esfincter externo do ânus no defecograma foi significantemente maior.

\section{REFERENCES}

1. Peña A, DeVries SPA- Posterior sagital anorectoplasty: important technical considerations and applications. J Pediatr Surg 1982; 17(6):796-811.

2. Haberkorn S, Mathias A L , Teixeira M G, et al. Defecograma: técnica simplificada e dados de interpretação. Rev Ass Med Bras 1978; 24(10):361-2.

3. Martins J L - Avaliação pós-operatória de crianças portadoras de anomalias anorretais submetidas a correção cirúrgica pela anorretoplastia sagital posterior. Tese de Docência Livre. Escola Paulista de Medicina. $111 \mathrm{p}, 1993$.

4. Siegel S - Estadistica parametrica. Ed.Trillas.Mexico. 346p, 1975.

5. Partridge J P \& Gough $\mathrm{M} \mathrm{H}$ - Congenital abnormalities of the anus and rectum. Brit J Surg 1961; 49:37-50.

6. Swenson O \& Donnellan W L - Preservation of the puborectalis sling in imperforate anus repair. Surg Clin North Amer 1967; 47:173-93.
7. Stephens F D \& Smith E D - Anorectal malformations in children. Year Book Medical Publishers. Chicago, 1971.

8. Templeton Jr J M \& Diteshein J A - High imperforate anus: quantitative results of long term fecal continence. J Pediatr Surg 1985; 20(6):645-52.

9. Langemeijeir R A T M \& Mollenaar J C - Continence after posterior sagital anorectoplasty. J Pediatr Surg 1991; 26(5):587-590.

10. Peña A - Posterior sagital approach for correction of anorectal malformations. Adv Surg 1986; 19:69-100.

11. Martins J L - Complicações no tratamento das anomalias anorretais.In:Margarido N F,Saad R, Cecconello I, Martins J L \& Soares L A - Complicações em Cirurgia. $1^{2}$ Ed. São Paulo: Ed.Robe, 1992:297-313.

12. Kelly J H - Cineradiography in anorectal malformations. J Pediatr Surg 1969; 4(5):538-46.

13. Kelly $\mathrm{J} H$-The clinical and radiological assesment of anal continence in childhood. Aust N Z J Surg 1972; 42(1):62-63.

14. Cywes S, Cremin B J \& Louw J H - Assesment of continence after treatment for anorectal agenesis: a clinical and radiologic correlation. J Pediatr Surg 1972; 6:132-137. 